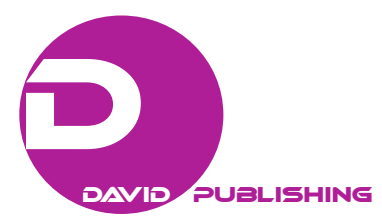

\title{
Financial Services Costs in Poland's Cooperative Banking in Opinion of Small and Medium-size Enterprise
}

\author{
Rafał Balina \\ Warsaw University of Life Sciences, Warsaw, Poland
}

\begin{abstract}
In their development strategy, Poland's cooperative (co-op) banks should equally consider the competition and the rising expectations of their clientele. According to bank customers, an essential element of customer satisfaction - which ties into their loyalty —is the cost of financial services. Currently, delivering a comfortable level of costs for financial services appears to be one of the key verifiers of a bank's offer, especially in a slowed economy. An effort was made to assess the satisfaction level of Poland's co-op bank clients from the small and medium enterprise (SME) sector based on costs for services offered by said banks. The study indicated that $2 / 3$ of the clientele was dissatisfied with high financial service and operation charges and low interest rates on current funds deposited by businesses. Co-op banks were able to deliver satisfactory interest rates for working capital loans in current accounts to over $60 \%$ of their clientele.
\end{abstract}

Keywords: client, satisfaction, financial services cost, cooperative (co-op) bank

\section{Introduction}

The last 20 years of the Polish cooperative (co-op) bank sector has seen many changes which have wrought many new and unexpected challenges. One of the most important factors before co-op banks causing changes is increasing competition, especially from foreign commercial banks and other financial institutions. Further, the clients' role and status have changed in relation to banks. As a result, many co-op banks have realigned their strategy to emphasis building strong relationships with their clientele. With time, co-op bank management started to realize that not only attracting new clients, but maintaining highly satisfied loyal clients with offered services may well insure success in the marketplace. Analysis indicates that a 5\% increase in the customer maintenance indicator may influence an increase of profits from 25 to $85 \%$ (Rudawska, 2005). This may suggest that client satisfaction and loyalty raise a bank's profits, consequently impacting expansion and bank equity for shareholders (Reichheld \& Teal, 2007).

Polish co-op banks must concentrate on maintaining their principal enterprise and strengthen their market share while re-focusing their strategy from product(s) to client(s) (Snarski, 2012). In the Polish banking system, the co-op banking sector has been identified with servicing rural areas exclusively, a result of where the idea of "cooperative" originated. Currently, there has been dynamic development and progress in this particular sector as seen in the expansion of co-op banks into large metropolitan areas which have been served primarily by the

Rafał Balina, Ph.D., Division of Banking, Department of Economics and Organization of Enterprises, Faculty of Economic Sciences, Warsaw University of Life Sciences-SGGW, Warsaw, Poland.

Correspondence concerning this article should be addressed to Rafał Balina, Nowoursynowska 166 str., 02-787 Warsaw, Poland. E-mail: rafal_balina@sggw.pl. 
commercial sector. Co-op banks frequently responded to the rising expectations of their clientele. As a result, the market position and conditions for the co-op banking sector started to change which stimulated competitiveness from commercial banking. This, in turn, places more significance on testing customer satisfaction in terms of co-op banking expansion. Furthermore, cognizance of customer satisfaction enables development of an effective competitive advantage in the market of banking services and products. Banks exist for their clienteles who then participate in creating the banks' present and future, indicating the important role of the customer - the confirmation of the banks' offer-in assessing the level of service quality (Stasiak-Betlejewska \& Borkowski 2010). The appropriate understanding of quality “...does not depend on sophisticated technology or complicated banking procedures, but on adjusting the banking offer to the needs of the individual client" (Rytelewska, 2011). This type of behavior contributes to maintaining current clientele (as well as attracting new customers) and increasing their willingness to pay the charges for said products and services (Skowron, 2010). The important source of such an effect is the organization's employees and their role in effecting value, satisfaction, and consequently, customer loyalty (Hill \& Alexander, 2004). Urbanek (2004) wrote about the strong ties among quality, satisfaction, and loyalty noting that the mentioned elements form a system and as such must be analyzed as a whole. The influence of customer satisfaction and loyalty on a bank's financial performance is evident (Skowron, 2010). The confirmation of this is the numerous benefits resulting from building a strong base of loyal and satisfied clients who are directly involved in a bank's profit growth. On the one hand, these satisfied loyal customers invest more in the products and services of given bank, because they are less sensitive to charge variability, among others, as confirmed by the research of Reichheld and Sasser (1990). On the other hand, these same clients contribute to reducing costs in several areas (Rudawska, 2002), such as lowered service costs (Reichheld \& Sasser, 1990), lowered costs of attracting new clients (Griffin, 1997), lowered costs as a result of cross-selling, and lowered marketing costs (Balina, Kowalski, \& Różyński 2014). Futrell's research (2004) indicated strong correlation among maintaining clients and their satisfaction and generated profits. Furthermore, the same study showed that clientele loyalty is one of the more essential factors for long-term company success. Other research draws attention to the profits which loyal clients are a source of (Dembińska-Cyran, Holub-Iwan, \& Perenc, 2004), such as profits from increased purchases, lowered operational costs, profits from referred customers, and profits from raised prices.

Satisfaction is defined as a feeling that is pleasant and gratifying associated with accomplishing or gaining something (Markowski \& Pawelec, 1989). Essentially, satisfaction is an emotional state which occurs in particular situations producing feelings of contentment upon the fulfillment of certain expectations, perceived benefits or solved problems. After making a purchase, there is an interface between the clients' expectations and their imagination or previous experience. This confrontation may induce a feeling of satisfaction or dissatisfaction in the case where the product or service does not fulfill one's expectations. The source of a client's expectations can be previous experience as well as earlier use of a bank's services, or given services of a competitor. Furthermore, these expectations may be generated from information given through marketing efforts. Equally significant as the above factors is the feedback of those who have taken advantage of said service or product.

It has been suggested that the quality of a service is decided by a matrix of five determinants, i.e., fixed assets representing the firm's credibility; reliability seen as thoroughness of a given service, responsiveness as in a bank's will to help a client, assurance of a bank's knowledge, and empathy demonstrated by the service provider to its clientele (Parasuraman, Zeithaml, \& Berry, 1991). Therefore, generating competitive offers by 
co-op banks which deliver the greatest benefits to the customer guarantees sufficient levels of client satisfaction-an essential challenge in the current market conditions. Thus, the market leaders are those institutions which not only fulfill given expectations, but also anticipate future needs, i.e. the client, purchasing some service, not only feels satisfaction, but in many cases is delight which then leads to long-term cooperation benefiting both parties - the customer and the financial institution, as is a bank (Chirau \& Sigauke, 2014)

Several authors confirm the association between satisfaction and clientele loyalty. Bloemer, de Ruyter, and Peeters (1998) indicated that in the realm of bank services, dependability and efficiency influence the levels of clientele loyalty. Similarly, Kheng, Mahamad, and Ramayah (2010) found a direct positive link among the quality of factors such as dependability, empathy and credibility, and clientele loyalty. However, the research of Kranias and Bourlessa (2013) indicated that the association between service quality and clientele loyalty is ambiguous. The only apparent correlation was that of bank location to client loyalty. Thus, current studies are focusing on the quality factors regarding a bank's services, i.e. staff competence, credibility and product innovation, and service charges, on clientele loyalty (Hys \& Hawrysz, 2013). Client satisfaction becomes not only the key for a bank's success, but critical in the campaign for customers in the highly competitive banking sector at present.

\section{Study Objective and Methodology}

The article undertakes to assess clientele satisfaction of co-op banks by SME's with regard to costs of financial services offered by said banks. The study incorporates 1,019 businesses from the SME sector which are clients of 50 randomly selected Polish co-op banks. The selected SME sector clients were requested to participate in an anonymous survey made up of 15 questions from the following topics: bank location, bank service charges, products, promotions, and bank service. The participants were to choose from a five step satisfaction scale- “decidedly no", "no", "no opinion”, “yes", and "decidedly yes". The study was carried-out in the first six months of 2013.

The following three questions were presented to the participants in order to realize the study objective:

- Does the interest rate on your company's current accounts match your expectations?

- Are the charges for services and operations competitive for the local market?

- Is the interest rate on working capital loans for current accounts acceptable?

The results are presented in the following diagrams.

The first question pertaining to interest rates of current accounts showed that $63 \%$ of the participants felt that it was adequate, ${ }^{1} 20 \%$ inadequate, and $17 \%$ had no opinion. Initial analysis may well shed an optimistic light since over $60 \%$ co-op bank clientele from the SME sector were satisfied with their conditions. However, the detailed analysis of the unsatisfied customers, when asked as to the source of their dissatisfaction, indicated higher interest rates availability at competitive banks (Figure 1).

The conviction of clients that higher interest rates are available in commercial banks is couched in the rivalry for effectively attracting new clientele. Commercial banks are willing to offer higher interest rates for accumulated funds in current accounts of businesses and sacrifice hose profits in order to gain long-term revenues.

\footnotetext{
1 To classify as an "adequate" answer, the participant had to answer "yes" or "decidedly yes"; conversely, to classify as "inadequate", the participant had to answer "no" or "decidedly no".
} 
The second analyzed element was the competitiveness of the co-op banks' charges for services and operations in the local market. Results, presented in Figure 2, indicate that over 2/3 of the participants were dissatisfied with the level of said charges. The clients of the co-op banks indicated that neighboring commercial banks offered SME sector businesses significantly lower charges. It bears noting that barely $14 \%$ of the participating businesses indicated satisfaction of charges, as compared to competitive offers.

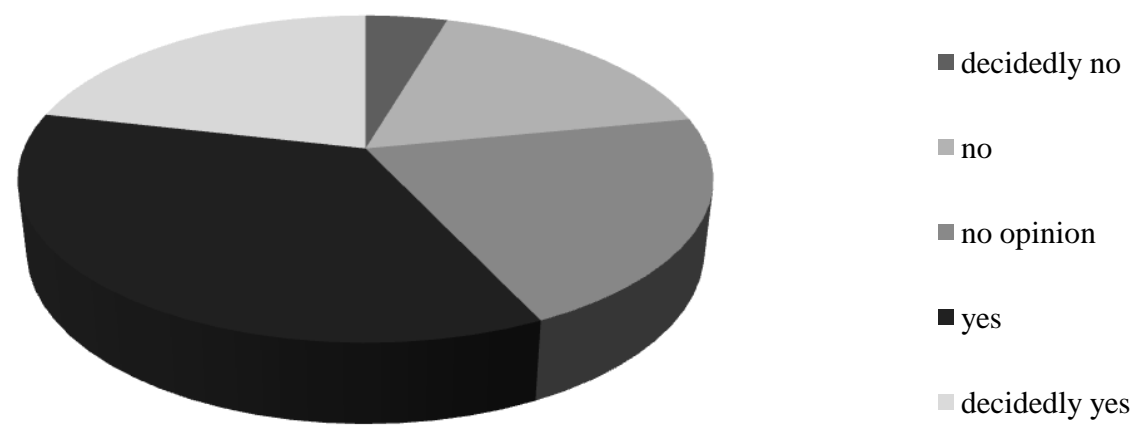

Figure 1. Does the interest rate on your company's current accounts match your expectations?

The negative rating of how high the charges are for services and operations results from the reluctance of people to pay for any additional costs, especially during a period of slowed economy. Further, clients of co-op banks are lured by dazzling advertisements of commercial banks offering free bank services; however, the offers pertain to internet banking and the charges for traditional banking activity are relatively the same as those in the cooperative banks.

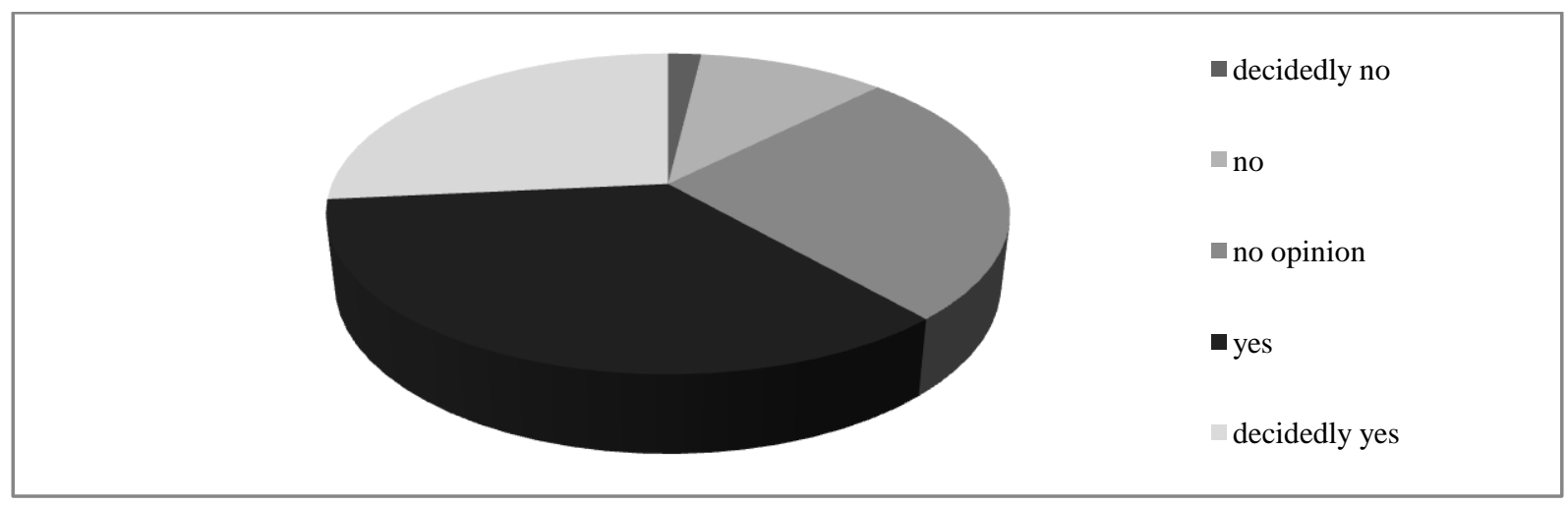

Figure 2. Are the charges for services and operations competitive for the local market?

In the case of the next question regarding the interest rate of working capital loans in current accounts, $62 \%$ of the surveyed participants were satisfied with the offer they took advantage of, or the offer which was proposed. Conversely, only $11 \%$ of those surveyed were dissatisfied with the interest rate for loans within their current accounts. This then means that Polish co-op banks meet the expectations of their clients in this respect (Figure 3).

For a full illustration of the issue of current account interest rates and interest rates for working capital loans, Poland's base interest rates are shown in Figure 4.

As is shown in Figure 4, both base interest rates were at record lows in 2013. Over the passage of the past 
few years, the steadily falling prime rates significantly restricted the maximum legal interest rate for consumer loans from $26 \%$ in 2008 , to $16 \%$ in 2013 . The systematic restrictions of prime rates by Poland's Monetary Policy Council (MPC) since 2011 could in fact influence the survey results presented in Figure 1 and 3. Of the objectives of MPC, one objective is to stimulate economic enterprise - on one hand the MPC caused a markedly restricted maximum interest rate for loans, and on the other, it caused a significant drop in paid interest on client's current accounts.

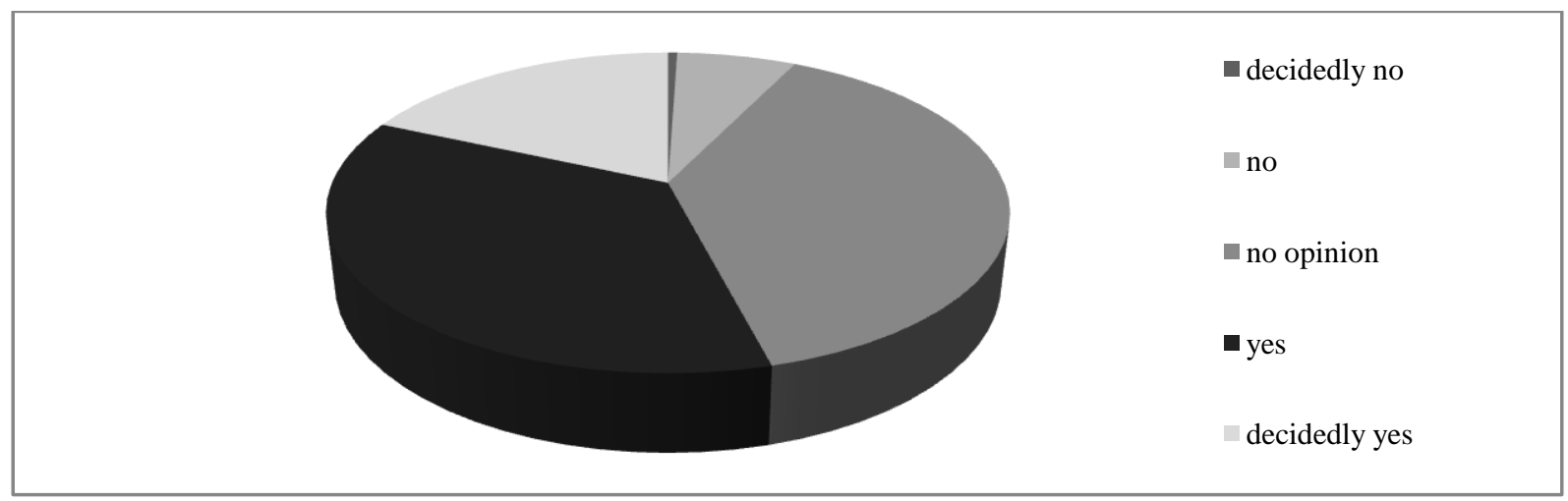

Figure 3. Is the interest rate on working capital loans for current accounts acceptable?

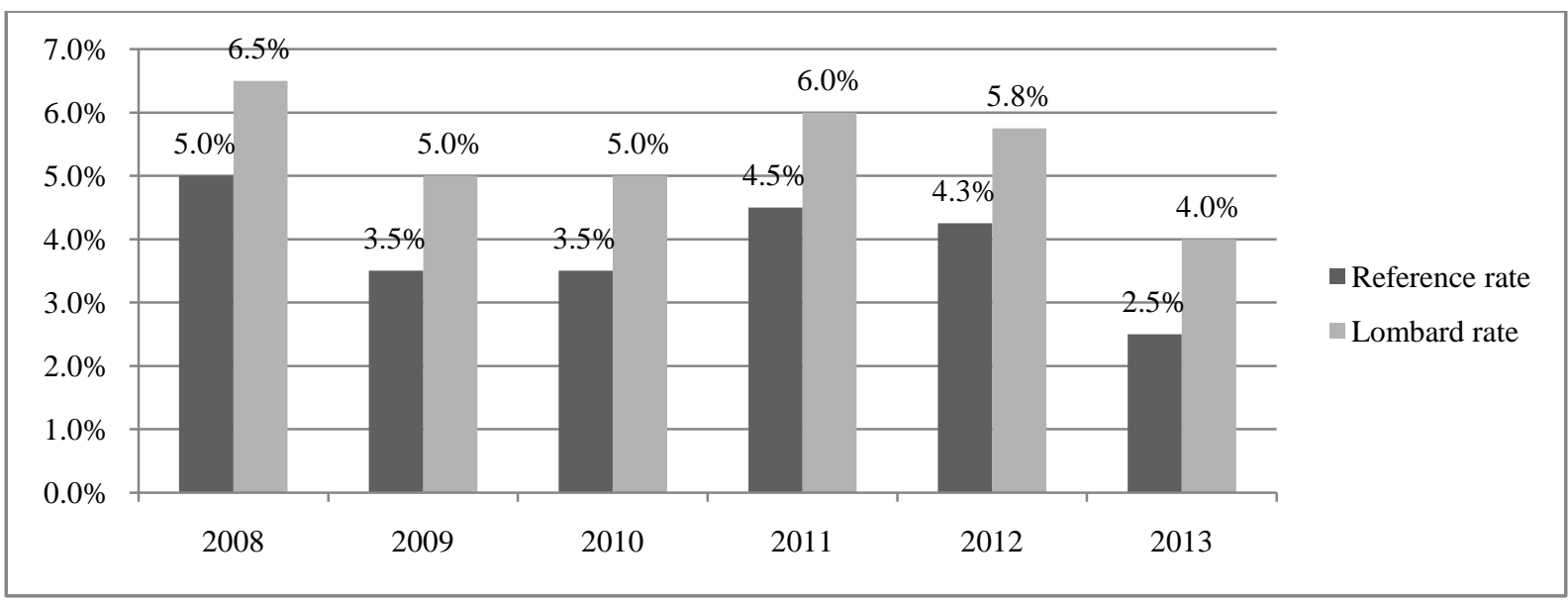

Figure 4. Base interest rates in Poland (\%).

Bank customers had previously adjusted to higher revenues generated by funds deposits in current accounts now negatively have assessed the level in interest currently offered by co-op banks. However, the significant drop in loan interest during this survey most certainly influenced the positive responses of the participants.

Co-op banks are an important part of many financial systems. In a number of countries, they are among the largest financial institutions when considered as a group. Moreover, the share of cooperative banks has been increasing in recent years. Contrary to some suggestions in the literature, it finds that co-op banks are more stable than commercial banks. This finding is due to the lower volatility of the cooperative banks' returns, which more than offsets their lower profitability and capitalization. This is most likely due to co-op banks' ability to use customer surplus as a cushion in weaker periods.

A particular characteristic of Poland's co-op banks—-personal attention—can be likened to the attention a 
customer gets from a clerk in a small shop: Both accurately remember what and when the customer made their last purchase; listen, understand, and adjust the merchandise to their needs, so that the client has the distinct impression that this product is "tailor-made" for them. This "impression" is an essential and unique facet in building the competitive advantage of cooperative banks, since the feelings of clients determine the market success of these banks.

\section{Conclusions}

Having the results of this study in mind, it appears that bank charges for services and operations are seen as high by the SME sector. The Polish co-op banks should endeavor to adjust their offer to the current conditions of the market in which they function. Conversely, the clientele indicates low interest rates on funds deposited in company current accounts where higher interest was offered by commercial banks which are boldly entering the market segment previously reserved for co-op banks. Yet, it must be noted that the interest rates charged by co-op banks on loans for current accounts of SME's pleased a principal part of the banks' clientele. This indicates an inclination or goodwill, on the part of co-op banks towards the SME sector which sector is the core of Poland's economy.

However, it would be a mistake to categorically accept the large number of negative opinions of the participants since the economic condition of the economy and sometime less than transparent marketing tactics of commercial banks may have influenced the clientele's views. Cooperative banks should continue to expand their offered financial instruments and services and adjust to the needs of their customers to insure the highest customer satisfaction possible. These efforts will undoubtedly and ultimately secure clientele loyalty and help accomplish stable levels of profit in the long-term perspective.

\section{Reference}

Balina, R., Kowalski, O., \& Różyński, J. (2014). Effective management of own funds in Polish cooperative banks. Chinese Business Review, 13(3), 156-156.

Bloemer, J., de Ruyter, K., \& Peeters, P. (1998). Investigating drivers of bank loyalty: The complex relationship between image, service quality and satisfaction. International Journal of Bank Marketing, 16, 276-286.

Chirau, R., \& Sigauke, S. (2014). A strategic perspective to small firms in relationship marketing: A case study of Francistown. Management Studies, 2(1), 21-34.

Dembińska-Cyran, I., Holub-Iwan, J., \& Perenc, J. (2004). Zarządzanie relacjami z klientami (Managing client relations). Wydawnictwo Difin, 1, 188-188.

Futrell, C. M. (2004). Nowoczesne techniki sprzedaży (Modern sales techniques). Oficyna Ekonomiczna, 1, 476-476.

Griffin, J. (1997). Customer loyalty. How to earn it, how to keep it. San Francisco: Jossey-Bass Publishers.

Hill, N., \& Alexander, J. (2004). Pomiar satysfakcji i lojalności klienta (The handbook of customer satisfaction and loyalty measurement). Warsaw: Oficyna Ekonomiczna.

Hys, K., \& Hawrysz, L. (2013). CSR in Poland as an important foundation of modern society. Management Studies, 1(1), 27-33.

Kheng, L., Mahamad, O., \& Ramayah, R. (2010). The impact of service quality on customer loyalty: A study of banks in Penang, Malaysia. International Journal of Marketing Studies, 2, 57-66.

Kranias, A., \& Bourlessa, M. (2013). Investigating the relationship between service quality and loyalty in Greek banking sector. Procedia Economics and Finance, 5, 453-458.

Markowski, A., \& Pawelec, R. (1989). Wielki Słownik Wyrazów Obcych i Trudnych (Great dictionary of foreign words). Warszawa: PWN.

Parasuraman, A., Zeithaml, V., \& Berry, L. (1991). Refinement and reassessment of the SERVQUAL scale. Journal of Retailing, 67, 420-450.

Reichheld, F. F., \& Sasser, Jr. W. E. (1990). Zero defections. Quality comes to service. Harvard Business Review, 68(9-10), 107-107. 
Reichheld, F., \& Teal, T. (2007). Efekt lojalności. Ukryta siła rozwoju firmy (Effect of loyalty. The hidden power of the company's development). Gliwice: Wydawnictwo Helion.

Rudawska, E. (2002). Marketing Partnerski—kształtowanie lojalności swoich klientów (Marketing partnership—how to shape the loyalty of your clientele). Przeglad Organizacji, 3(6), 38-38.

Rudawska, E. (2005). Lojalność klientów. Warszawa: PWE.

Rytelewska, G. (2011). Bankowość detaliczna strategią konkurencji wobec banków zagranicznych (Retail banking-competition strategy in the face of foreign banks). Warsaw: SGH Katedra Bankowości.

Skowron, S. (2010). Wpływ satysfakcji i lojalności klienta na wyniki finansowe przedsiębiorstwa (The influence of client satisfaction and loyalty on commercial financial results). In G. Rosa, \& A. Smalec (Eds.), Marketing przyszłości-Trendy, Strategie. Instrumenty (Marketing the future-trends, strategies. Instruments). Szczecin: Economic Problems of Services.

Snarski, P. (2012). Metody pomiaru satysfakcji klientów bankowych wykorzystywanych do analiz konkurencyjności banków (Bank client satisfaction assessment methods used for bank competitiveness analysis). Economy and Management, 4(2), 92-93.

Stasiak-Betlejewska, R., \& Borkowski, S. (2010). Identyfikacja poziomu satysfakcji klienta banku w procesie usługowym przy wykorzystaniu metody servqual (Identifying client satisfaction levels in the service process applying the Servqual method). Zeszyty Naukowe Polityki Europejskie, Finanse i Marketing, 3(52), 69-69.

Urbanek, G. (2004). Jakość, satysfakcja, rentowność—lańcuch przyczynowo-skutkowy (Quality, satisfaction, profitability-the cause and effect chain). Marketing i Rynek, 8(6), 2-8. 